\title{
The Empirical Study of Shareholding Structure and Firm Performance in China
}

\author{
Liling Yang \\ Economics \& Management College \\ Zhaoqing University \\ Zhaoqing, China
}

\author{
Pocheng Ko \\ Topoint Technology Co., Ltd. \\ Taipei, China
}

\begin{abstract}
Three research hypotheses are proposed for the relationship between enterprise performance and ownership structure by measuring enterprise performance with economic value added. The empirical results show that hypothesis 1 is supported; the ratio of state shares is negatively correlated with corporate performance. Hypothesis 2 is not supported; there is insignificantly negative correlation between the ratio of legal person shares and corporate performance. There is a significant positive correlation between listed stocks and corporate performance supporting hypothesis 3 .
\end{abstract}

Keywords-shareholding structure; firm performance; economic value added

\section{INTRODUCTION}

Due to the separation of ownership and management, controlling shareholders can often occupy the resources of enterprises and infringe on the interests of minority shareholders. [1] In recent years, due to the defects of corporate governance, there have been many cases of fraud around the world. These include the China Yuanhua case in 1996, the Enron and Worldcom scandals in the us in 2001 and the Procomp scandal in Taiwan in 2004.In these cases, ownership structure were proved to affect corporate governance and thus corporate performance.

With the rapid flow of international capital and the rapid growth of China's economy, investors from other countries are paying more and more attention to the study of Chinese enterprises. First, China's equity structure is seriously unbalanced, with the government taking an obvious majority in the equity structure and the Chinese government having absolute control over enterprises. [2]. Second, China's stock transfer policy is strict and the external influence is seriously weakened. Qiang (2003) points out that in Chinese government enterprises, most managers are appointed by the government. Since promotion is determined by government standards rather than enterprise performance, managers' enthusiasm is not high, leading to the decline of corporate management performance. [3] Clarke (2003) pointed out that in Chinese government enterprises, all people, from the central government to employees, are agents. The multiple agency relationships of Chinese companies lead to different internal goals and different departmental opinions, making it difficult to achieve profit goals.[4].Many studies have shown that state-owned enterprises have a negative correlation with their corporate performance, while enterprises with a high proportion of corporate ownership and public shares have a positive correlation with their performance. In this study, we examine the relationship between ownership structure and corporate performance of Chinese listed companies from 2005 to 2010, economic value added (EVA) is used as a tool to evaluate the relationship between corporate governance performance and ownership structure.

\section{LITERATURE AND HYPOTHESIS}

In China, the government owns an absolute majority stake in the company, at the under insufficient stock circulation and strict transfer system, making it difficult for China's capital market to reach its full potential. Many studies show that concentrated ownership by institutional owners can bring a positive effect on firm performance [5], inappropriate level of ownership concentration can bring negative effects on firm performance [6] The state shareholding can also have negative impact on firm performance [7]. When the proportion of state shares is high, the relationship between multiple institutions and internal human resource control problems reduce the incentive for managers. On the contrary, if the corporate ownership ratio is high, the above problems will be reduced. Managers are more likely to work for the benefit of the company and to supervise management more actively. Therefore, we predict that lower state shares and higher legal shares, as well as greater stock liquidity, can improve the management performance of the company. We propose the following three hypotheses:

H1: The state shareholding ratio is negatively correlated with corporate performance.

$\mathrm{H} 2$ : The legal shareholding ratio is positively correlated with corporate performance.

H3: The public shares proportion is positively correlated with corporate performance.

According to past research literature, this study considers the following as control variables:

Ownership Concentration: the more ownership concentration, the greater supervision power. The direct participation of the largest shareholder in management can 
department or institution with government capital divided by total circulating shares.

Legal shares proportion: Legal shares are shares issued by an enterprise to both domestic and foreign investors calculated according to the proportion of legal shares divided by total circulating shares.

Public shares proportion: Public shares divided by total circulating shares.

3) Control variables: According to past research literature, this study considers the following as control variables, as described below:

Ownership Concentration: the largest shareholder ratio to measure this variable.

Board-held shares proportion: the board-held shares proportion is used to measure this variable.

Independent board members proportions: independent board members proportions.

Board size: board of seats at the end of $t$ years.

Company size: company's total assets as the proxy variable of company size.

Debt: debt as a percentage of total assets.

Return on assets (ROA): net income as a percentage of total assets.

Year: A specific fiscal year is designated, with 1 as dummy variable, and the rest years as 0 . This study covers 6 fiscal years from 2005 to 2010.Six dummy variables are set.

4) Empirical model: In order to test hypothesis 1: The state shares proportion is negatively correlated with corporate performance, the following empirical model was used:

Model 1:

$\mathrm{EVA}^{\circledR i t}=\alpha \mathrm{i}+\beta 1$ Stateit $+\beta 2 \mathrm{OCit}+\beta 3$ Boardit + $\beta$ 4ndepit $+\beta 5$ Bsizeit $+\beta 6$ Sizeit $+\beta$ DDebtit $+\beta 8$ ROAit + $\Sigma \beta 9$ Yearit + eit

In order to test hypothesis 2: The legal shares proportion is positively correlated with corporate performance, the following empirical model was used:

Model 2:

$\mathrm{EVA}^{\circledR i t}=\alpha \mathrm{i}+\beta 1$ Legal it $+\beta 2 \mathrm{OCit}+\beta 3$ Boardit + $\beta 4$ Indepit $+\beta 5$ Bsizeit $+\beta 6$ Sizeit $+\beta$ Debtit $+\beta 8$ ROAit + $\Sigma \beta 9$ Yearit + cit

In order to test hypothesis 3: The Public shares proportion is positively correlated with corporate performance, the following empirical model was used:

Model 3:

$\mathrm{EVA}^{\circledR i t}=\alpha \mathrm{i}+\beta 1$ Public it $+\beta 2$ OCit $+\beta 3$ Boardit + $\beta 4$ Indepit $+\beta 5$ Bsizeit $+\beta 6$ Sizeit $+\beta$ Debtit $+\beta 8$ ROAit + $\Sigma \beta 9$ Yearit + eit

i represents the ith company, t means t years.

Shares purchased by a government-approved investment 
(EVA).The research objects are listed companies in China. The research spanned from 2005 to 2010 and selected 947 listed companies. As can be seen from "Table I", the mean value of the dependent variable EVA is $219,322.76$, with a maximum value of 58,912,905.57 dollars and a minimum value of $-28,356,740.42$ dollars. The huge gap between maximum value and minimum value represents the huge gap in the value of Chinese enterprises. Among the experimental variables, the mean proportion of state shares and legal shares is 21.23 and 15.16 respectively. The mean is less than the standard deviation; In addition, there is a large gap between the maximum and minimum values. This result conveys a large change in three variables. In recent years, the proportion of state shares has been declining, but it still accounts for one fifth of the total number of shares on average. The average value of public shares is 56.88 , but the gap between the maximum and minimum value is still wide. The average value of ownership concentration (OC) is 53.08, indicating a high ownership concentration in China.

\section{EMPIRICAL RESULT AND ANALYSIS}

\section{A. Descriptive Statistics}

This study mainly examines the relationship between ownership structure and corporate performance in China, and measures corporate performance by economic added value

TABLE I.

The Descriptive Statistics of EACH VARIABLE

\begin{tabular}{|c|c|c|c|c|}
\hline & Mean & Standard Deviation & Minimum Value & Maximum Value \\
\hline EVA® & 219,322 & $1,722,000$ & $28,356,740$ & $58,912,905$ \\
\hline State & 21.23 & 23.86 & 0.00 & 86.20 \\
\hline Legal & 15.16 & 20.92 & 0.00 & 87.95 \\
\hline OC & 53.08 & 17.12 & 1.31 & 97.01 \\
\hline Board & 3.63 & 11.49 & 0.00 & 73.03 \\
\hline Indep & 0.36 & 0.05 & 0.00 & 0.75 \\
\hline Bsize & 9.3 & 1.96 & 4.00 & 19.00 \\
\hline Size & 6.39 & 0.52 & 2.35 & 8.99 \\
\hline Debt & 52.73 & 29.64 & 0.00 & 714.39 \\
\hline ROA & 5.32 & 9.76 & -174.51 & 233.13 \\
\hline
\end{tabular}

EVA: economic value added; State: the ratio of state shares; Legal: the ratio of legal person shares; Public: the ratio of public shares; OC: ownership concentration; Board: the ratio of board shareholding; Indep: the ratio of independent directors (seats); Bsize: the size the board (seats); size: the size of firms; Debt: debt ratio; ROA: return on assets.

\section{B. Correlation Analysis}

"Table II" shows the correlation coefficients of each variable. The lower left is the result of Pearson's correlation coefficient and the upper right is the result of Spearman's correlation coefficient. The correlation coefficient between all variables in the table is less than 0.7 . Therefore, it can be inferred that collinearity between variables is not a serious problem in general. 
TABLE II. MATRIX OF CORRELATION COEFFICIENTS

\begin{tabular}{|c|c|c|c|c|c|c|c|c|c|c|c|}
\hline & EVA® & State & Legal & Public & OC & Board & Indep & Bsize & Size & Debt & ROA \\
\hline \multirow{2}{*}{ EVA® } & 1 & -.008 & -.132 & .033 & .183 & .054 & .013 & .147 & .558 & .026 & .276 \\
\hline & & .575 & .000 & .022 & .000 & .000 & .362 & .000 & .000 & .069 & .000 \\
\hline \multirow{2}{*}{ State } & .038 & 1 & -.322 & -.424 & .393 & -.270 & -.078 & .187 & .146 & .032 & -.079 \\
\hline & .008 & & .000 & .000 & .000 & .000 & .000 & .000 & .000 & .025 & .000 \\
\hline \multirow{2}{*}{ Legal } & -.047 & -.420 & 1 & -.354 & .122 & .045 & -.038 & -.063 & -.227 & .076 & .029 \\
\hline & .001 & .000 & & .000 & .000 & .002 & .008 & .000 & .000 & .000 & .045 \\
\hline \multirow{2}{*}{ Public } & -.039 & -.410 & .899 & 1 & .089 & .080 & -.031 & -.072 & -.216 & .049 & .032 \\
\hline & .008 & .000 & .000 & & .000 & .000 & .030 & .000 & .000 & .001 & .025 \\
\hline \multirow{2}{*}{ OC } & .119 & .444 & .231 & -.382 & 1 & -.356 & -.060 & .139 & .185 & .020 & .106 \\
\hline & .000 & .000 & .000 & .000 & & .000 & .000 & .000 & .000 & .177 & .000 \\
\hline \multirow{2}{*}{ Board } & -.022 & -.260 & -.060 & -.219 & -.492 & 1 & -.027 & -.018 & -.116 & -.025 & .254 \\
\hline & .124 & .000 & .000 & .000 & .000 & & .067 & .216 & .000 & .080 & .000 \\
\hline \multirow{2}{*}{ Indep } & -.032 & -.079 & -.020 & .050 & -.061 & .056 & 1 & -.240 & .019 & .010 & .011 \\
\hline & .026 & .000 & .170 & .001 & .000 & .000 & & .000 & .197 & .477 & .463 \\
\hline \multirow{2}{*}{ Bsize } & .101 & .165 & -.085 & -.056 & .146 & -.110 & -.262 & 1 & .270 & .080 & .035 \\
\hline & .000 & .000 & .000 & .000 & .000 & .000 & .000 & & .000 & .000 & .016 \\
\hline \multirow{2}{*}{ Size } & .288 & .164 & -.201 & .078 & .247 & -.217 & .023 & .303 & 1 & .227 & -.011 \\
\hline & .000 & .000 & .000 & .000 & .000 & .000 & .104 & .000 & & .000 & .439 \\
\hline \multirow{2}{*}{ Debt } & -.009 & .006 & .077 & -.046 & .046 & -.036 & .003 & .023 & .067 & 1 & -.219 \\
\hline & .555 & .669 & .000 & .002 & .001 & .013 & .840 & .106 & .000 & & .000 \\
\hline \multirow{2}{*}{ ROA } & .039 & -.046 & .039 & -.118 & .001 & .223 & .036 & .002 & -.027 & -.237 & 1 \\
\hline & .007 & .001 & .007 & .000 & .959 & .000 & .013 & .870 & .061 & .000 & \\
\hline
\end{tabular}

The lower left corner displays Pearson correlation coefficients, and the upper right corner exhibits Spearman correlation coefficients.

EVA: economic value added (RMB million); State: the ratio of state shares; Legal: the ratio of legal person shares; Public: the ratio of public shares; OC: ownership concentration; Board: the ratio of board shareholding; Indep: the ratio of independent directors (seats); Bsize: the size the board (seats); size; the size of firms; Debt: debt ratio; ROA: return on assets.

\section{The Analysis of Empirical Result}

This study treats economic value added as the dependant variable to test the correlation between ownership structure and firm performance in China, and evidence the hypotheses with multivariate regression analysis respectively. "Table III" shows that all variable VIF values is less than 10 . The results show that there is no collinearity between variables.

To test the hypothesis 1: the correlation between the ratio of state shares and firm performance is negative. An empirical research is conducted with Model 1, and its result is registered in Table 3. The empirical result shows: the coefficient between the ratio of state shares (State) and economic value added (EVA) is -2868.936 , which conveys significant negative correlation (the significance level reaches 5\%). The result supports the hypothesis 1 - the higher the ratio of state shares is, the lower the firm performance is.

Test hypothesis 1: the proportion of state shares is negatively correlated with corporate performance. Model 1 was used for empirical research, and the empirical results showed that the proportion of state shares was significantly negatively correlated with economic added value $(\mathrm{t}=-2868$, significance level reached 5\%)(see Table 3). The results support hypothesis 1 , the higher the proportion of state shares, the lower the corporate performance.

Test hypothesis 2: legal shareholding ratio is positively correlated with corporate performance. Model 2 is adopted for empirical research, and the results are shown in "Table III". The empirical results show that there is no significant negative correlation between legal shareholding ratio and economic value added $(\mathrm{t}=-520)$, hypothesis 2 is not proven.

One possibility is that both legal and state shares are nontradable and cannot be listed or traded on exchanges. In addition, the Chinese government sets strict restrictions on transfers, which hinder market investors' supervision of business operations and the proper market mechanism. It also hinders the speed of capital flow and the flexible use of enterprise capital. In addition, the legal person can consider his own profit, which is in conflict with the profit of the invested enterprise. When the shareholding ratio of legal persons increases, the influence of legal persons on the invested enterprises will be relatively expanded. Therefore, the profits of the invested enterprises can be transferred to the legal person through transfer pricing. In addition, legal person shares may also be manipulated by the short-selling mechanism, which can make arbitrage profits by driving down the share price, or by deliberately raising the share price by releasing information, which damages the long-term profits of enterprises. Therefore, this negative influence may lead to the insignificance of the empirical results.

To test the hypothesis 3: the correlation between the ratio of public shares and firm performance is positive. An empirical research is conducted with Model 3, and its result is registered in "Table III". The empirical result shows that the coefficient between the ratio of public shares and economic value added is 2687.854 , which proves significant positive correlation (the significance level reaches $5 \%$ ). The result supports the hypothesis 3 , the higher the ratio of public shares is, the better corporate performance.

In terms of control variables, the three models manifest the results as follows: ownership concentration (OC) is significant positive correlation, showing that the more ownership concentrates, the better firm performance. The result is the same as expected. The empirical result of the ratio of board shareholding (Board) is significant positive correlation, which is the same as expected, the higher the ratio of boarding shareholding, the better firm performance. The empirical result of the ratio of independent director 
Model 2, but all of them do not reach the significance level; therefore, the size of board is not much related to firm performance. The size of firm (Size) is positively correlated with expectation in empirical results. Therefore, the larger the enterprise scale, the better the enterprise performance. The debt ratio (debt) is negatively correlated with the empirical results, but all results do not reach a significant level, so the debt ratio is not highly correlated with enterprise performance. Return on assets (ROA) is positively correlated; Model 1 did not reach the level of significance, and model 2 and model 3 showed a significant positive correlation.

TABLE III. EMPIRICAL RESULT

\begin{tabular}{|c|l|l|l|}
\hline & \multicolumn{1}{|c|}{ Model 1 } & \multicolumn{1}{c|}{ Model 2 } & \multicolumn{1}{c|}{ Model 3 } \\
\hline Constant(t value) & $-6003458(-5.89)$ & $-5819546(-15.42)$ & $-6176243(-14.91)$ \\
\hline State & $-2868\left(-2.40^{* *}\right)$ & -- & -- \\
\hline Legal & -- & $-52(-.42)$ & -- \\
\hline Public & -- & -- & $2687\left(1.81^{* * *}\right)$ \\
\hline OC & $10162\left(5.79^{* * *}\right)$ & $8951\left(5.23^{* * *}\right)$ & $11035\left(5.32^{* * * *}\right)$ \\
\hline Board & $11769\left(4.717^{* * * *}\right)$ & $1193\left(4.78^{* * *}\right)$ & $14985\left(4.97^{* * * *}\right)$ \\
\hline Indep & $-1343352\left(-72^{* * * *}\right)$ & $-1340531\left(-.72^{* * *}\right)$ & $-1319574\left(-.67^{* * *}\right)$ \\
\hline Bsize & $1740(.13)$ & $-455(-.03)$ & $171(.013)$ \\
\hline Size & $970406\left(18.64^{* * *}\right)$ & $950224\left(17.979^{* * *}\right)$ & $951474\left(18.40^{* * *}\right)$ \\
\hline Debt & $-1336(-1.62)$ & $-1238(-1.49)$ & $-1173(-1.42)$ \\
\hline Roa & $4062(1.56)$ & $4458\left(1.71^{*}\right)$ & $4409\left(1.70^{*}\right)$ \\
\hline Y05 & $-14112(-.15)$ & $-75777(-.83)$ & $11680(.11)$ \\
\hline Y06 & $73268(.81)$ & $21740(.25)$ & $100028(1.01)$ \\
\hline Y07 & $203121\left(2.34^{* * *}\right)$ & $161596\left(1.89^{*}\right)$ & $226890\left(2.44^{* * *}\right)$ \\
\hline Y08 & $-167705(-1.98)$ & $-201512\left(-2.41^{* *}\right)$ & $-150098\left(-1.70^{*}\right)$ \\
\hline Y09 & $22858(.28)$ & $11237(.14)$ & $35516(.43)$ \\
\hline F value & 40.15 & 36.68 & 39.94 \\
\hline Adj. $\mathbf{R}^{2}$ & 0.10 & 0.10 & 0.10 \\
\hline & & & \\
\hline
\end{tabular}

Note1:*** $1 \%$ significance level; $* * 5 \%$ significance level; * 10\% significance level. b. Note2: The variable definitions are the same as in table 4 .

d. Note4:Control variables in the three models VIF are: OC:1.46,1.53,2.25. e. Board:1.1,1.46,2.14 ; Indep:1.22,1.1,1.1 ; Bsize:1.29,1.22,1.21 f. Size:1.07,1.32,1.27; Debt:1.45,1.08,1.08Roa:1.96,1.46,1.14

\section{CONCLUSION}

This study examines the relationship between ownership structure and corporate performance of Chinese listed companies from 2005 to 2010 . Three research hypotheses are proposed for the relationship between enterprise performance and ownership structure by measuring enterprise performance with economic value added .The empirical results show that hypothesis 1 is supported, the ratio of state shares is negatively correlated with corporate performance. The results show that the Chinese government's strict supervision on the transfer of state shares reduces the supervision and restraint mechanism on the management through the acquisition market and agency competition. In addition, the state shares also involve multiple agency relationship. From the central government to the employees of the enterprise, they are all agents. When these agents pursue different goals, they naturally do not take corporate performance as the main consideration. This multilevel relationship increases moral hazard.

Hypothesis 2 is not supported. There is insignificantly negative correlation between the ratio of legal person shares and corporate performance. This is different from the conclusion drawn by most previous studies that the ratio of legal person shares is positively correlated with corporate performance. This may be the previous literature adopted traditional performance measurement indicators, but this study adjusted from the perspective of economic added value (EVA). The actual value of enterprises is negatively correlated with the ratio of legal person shares That is, the larger the ratio of legal person, the worse the company 
performance. It is speculated that may be because both legal person shares and state shares are non-tradable shares, hindering the operation of the market mechanism. The introduction of institutional investors is often seen as connecting with the world, however, when the relevant complementary market regulatory mechanisms are not sound, even if the introduction of institutional investors is expected to improve the market environment, it will not bring much benefit.

Finally, there is a significant positive correlation between listed stocks and corporate performance supporting hypothesis 3. This result shows that listed stocks are the outstanding stocks traded on the stock market and have the characteristics of "voting with feet" in corporate governance. Once the public shareholding ratio and external regulatory forces increase, the management will face greater pressure to work hard. Therefore, when using EVA to measure corporate performance, the ratio of state shares and listed shares have significant impact on corporate performance in China.

\section{REFERENCES}

[1] Fan and Wong. Corporate Ownership Structure and the Informativeness of Accounting Earnings in East Asia. Journal of Accounting and Economics 33, 2002, pp.401-425.

[2] $\mathrm{Xu}, \mathrm{X}$, and $\mathrm{Y}$, Wang. Ownership structure and corporate and governance in Chinese stock companies. China Economic Review10,1999,pp.75-98.

[3] Qiang, Q. Corporate governance and state-owned shares in China listed companies. Journal of Asian Economics 14, 2003,pp.771-783.

[4] Clark, D.C. Corporate governance in China: An overview. China Economic Review 14, 2003,pp.494-507.

[5] Elyasiani, E., \& Jia, J.. Distribution of Institutional Ownership and Corporate Firm Performance. Journal of Banking \& Finance, 34(3), 2010, pp.606-620.

[6] Dahya, J., Dimitrov, O., and McConnell, J. J., Dominant Shareholders, Corporate Boards, and Corporate Value: A Cross-country Analysis. Journal of Financial Economics,87(1),2008,pp.73-100.

[7] Chang, E. C., and Wong, S. M. L. Political Control and Performance in China's Listed Firms. Journal of Comparative Economics. 32(4),2004,pp.617-636.

[8] Jensen, M. C. and W. H. Mecking. Theory of the Firm: Managerial Behavior, Agency Costs and Ownership Structure. Journal of Financial Economics 3 (4), 1976,pp.305-360.

[9] Jensen, M. C. and R. S. Ruback. The Market for Corporate Control: The Scientific Evidence. Journal of Financial Economics 11, 1983,pp.5-50.

[10] Baysinger, B. D. and H. N. Butler. Corporate Governance and the Board of Directors: Performance Effects of Changes in Board Composition. Journal of Law, Economics, and Organization 1, 1985,pp.101-124.

[11] Hermalin, B. E. and M. S. Weisbach. The Effects of Board Composition and Direct Incentives on Firm Performance. Financial Management 20, 1991,pp.101-112.

[12] Bacon. Corporate Directorship Practices: Membership and Committees of the Board.: Vol. 26 Iss 3, 1973,p.457-457. 